M.O. Fomina ${ }^{1}$, I.V. Dabrowska', K.S. Tkachenko ${ }^{1}$, V.S. Pidgorskyi ${ }^{1}$

${ }^{1}$ Institute of Microbiology and Virology, NASU,

154 Academ. Zabolotny Str., Kyiv, 03143, Ukraine

${ }^{2}$ Educational and Scientific Centre "Institute of Biology"

of Taras Shevchenko National University of Kyiv,

64/13 Volodymyrska Str., Kyiv, 01601, Ukraine

\title{
PH EFFECT ON ANTAGONISTIC ACTIVITY TOWARDS BACTERIA OF YEASTS ISOLATED FROM HUCUL DAIRY PRODUCTS AND GASTROINTESTINAL TRACT OF HUMAN
}

The aim of this work was to study the influence of $\mathrm{pH}$ of medium on antagonistic activity of isolated from authentic Hucul dairy products and gastrointestinal tract (GIT) of Hucul long-livers yeasts towards potentially harmful for humans and animals bacteria. Among 52 tested yeast isolates $14 \%$ yeasts showed considerable antagonistic activity towards Gram-positive bacteria Staphylococcus aureus and only $6 \%$ of them inhibited growth of Gram negative bacteria belonging to genera Escherichia and Citrobacter. Most of yeasts with antagonistic activity (over $70 \%$ ) were isolated from long-livers GIT. There were identified two optimal for antagonism areas of $\mathrm{pH}$ values of nutrient medium for tested yeasts being around 5.5 and 6.0 for Gram-positive bacteria and around 6.0 and 6.5 for Gram negative bacteria. It appeared that isolated from Hucul yogurt Saccharomyces pasterianus yeasts manifested their antagonistic activity in more acidic conditions compared to isolates from GIT.

K e y words: yeast, antagonistic activity, pH, dairy products, GIT.

Being unicellular microeukaryotes belonging to phylogenetically different groups of fungi yeasts are widely distributed in the environment and an essential compound in many complex ecosystems [2].

Yeasts are commonly found in milk and dairy products. Yeasts appear in milk just in a few hours after the milking process reaching at least $13 \%$ of the total number of microorganisms. The yeasts found in milk belonged predominantly to genera Candida, Pichia, Rhodotorula and Saccharomyces [4].

Yeasts are also an important part of the normal microbiota of human and animals. It was reported that in the human body they were found mostly in saliva, skin and mucous membranes, gastrointestinal tract (GIT) and belonged to over 170 species and 25 genera [6].

Like other microscopic fungi yeasts can take an active part in various interactions with other microorganisms and macroorganisms including symbiosis, mutualism, parasitism and competition [2].

As a large and heterogeneous group of microorganisms of the great practical importance yeasts have been always of particular interest. Numerous versatile properties make them promising candidates for a wide range of applications not limited just to the food sector of industry $[1,12,13]$. One of the growing areas of interest is currently the application of certain yeasts in healthcare. 
Yeasts can manifest pronounced antagonistic effect towards various groups of microorganisms including bacteria and other yeasts and filamentous fungi $[8,13]$. It provides yeasts competitive advantages by creating unfavorable conditions for other microorganisms growth and development. This antagonistic activity of yeasts can be contributed by biosynthesis of specific substances like mycocins and bacteriocins as well as by nonspecific metabolites altering environmental conditions [11].

The particular importance of yeasts in treating and prevention of the gastrointestinal tract diseases is fully recognized nowadays. There are increasing global trends for using yeasts as food supplements, probiotic product etc.

One of the requirements for the microbial probiotics is their ability to survive the passage through the gastrointestinal tract of humans and animals. It is known that, when taken orally, the best commercially established preparation of yeast probiotic Saccharomyces boulardii showed the 1-3\% rate of cells survival in the distal part of large intestine. It was also shown that $S$. boulardii can survive in the range of $\mathrm{pH}$ from 2 to 6.3 [7].

Currently there is a lack of data on the influence of $\mathrm{pH}$ on yeast survival under conditions of the gastrointestinal tract and only single studies on the $\mathrm{pH}$ effect on the yeasts antagonism towards bacteria. For example, for Saccharomyces cerevisiae isolates from human GIT the highest values of antagonistic activity towards pathogenic and opportunistic pathogenic bacteria were observed at range $\mathrm{pH}$ 5.5-6.5 [3].

The aim of this study was to investigate the effect of $\mathrm{pH}$ on the antagonistic activity against opportunistic pathogenic bacteria manifested by yeasts isolated from authentic Hucul dairy products and GIT of Hucul long-livers.

Materials and methods. Microorganisms. Yeasts were 52 cultures isolated from the authentic Hucul homemade dairy products and representing the distal part of large intestine GIT samples taken from Hucul long-livers of the highland region of the Eastern Carpathians, Ukraine. The dairy products were sour cream, Hucul yogurt Guslinka and home-made cheese (Table 1). The conventional dilution method and the malt agar medium were used for yeasts isolation.

The reference strains of bacterial cultures for testing antagonistic activity of yeasts were Staphylococcus aureus ATCC 25923 and Escherichia coli ATCC 25922 from Ukrainian collections of microorganisms. There were also tested 3 strains of bacteria Escherichia coli 1621, Citrobacter freundii 1603, Citrobacter intermedius 1555 isolated from healthy air transport workers at their routine examination performed by the Central Sanitary and Epidemiological Station of

\section{Table 1}

The sources of yeasts isolates

\begin{tabular}{|c|c|c|}
\hline Sources & Number of yeasts strains & Total number \\
\hline Guslinka & $\begin{array}{c}\text { F2, F21, F23, F25, FF1,FF2, FF5, FF6, FF7, FF8, } \\
\text { FF9, FF10, FF11, FF12, FF13, FF18 }\end{array}$ & 16 \\
\hline Sour cream & FF4, FF14, FF15, FF16, FF18 & 5 \\
\hline Homemade cheese & F15, F27, F28, F29, F31, F35, F36 & 7 \\
\hline Long-livers GIT & $\begin{array}{c}\text { S1, S2, S3, S4, S5, S7, S10, S11, S12, S13, S14, } \\
\text { S15, S16, S17, S19,S21, S22, S23, S24, S25, S28, } \\
\text { S30, S31, S32 }\end{array}$ & 24 \\
\hline
\end{tabular}


Air Transport in Ukraine, Kiev. The preliminary identification of 7 yeasts isolates with highest antagonistic activity was performed using a standard scheme of phenotypic identification by Kurtsman [10].

Yeast and bacterial strains were maintained on malt agar and meat-peptone agar (MPA), correspondently.

Antagonistic activity evaluation. The conventional agar plug method was used to evaluate the antagonistic activity of yeasts isolates towards bacteria. Prior to the tests the microorganisms were grown for 24 hours at $28{ }^{\circ} \mathrm{C}$ for yeast and at $37^{\circ} \mathrm{C}$ for bacteria. To prepare the agar plugs with yeasts biomass for tests were initially prepared by plating $1 \mathrm{ml}$ of yeasts cell suspension $\left(6 \times 10^{8}\right.$ cells $\left.\mathrm{mL}^{-1}\right)$ on the malt agar medium $(20 \mathrm{ml}$ per plate $)$ with different $\mathrm{pH}$ values: 5.0, 5.5, 6.0, 6.5 and 7.0. The $\mathrm{pH}$ adjustment was performed using sterile citrate-phosphate buffer before pouring the plates. The yeasts cultures were incubated at $28{ }^{\circ} \mathrm{C}$ for $72 \mathrm{~h}$ and then a sterile 8 -mm-diameter cork borer was used to cut the agar plugs.

The cell suspensions of 24 hours-old bacterial cultures $\left(1 \mathrm{~mL}, 1.5 \times 10^{8}\right.$ cells $\mathrm{mL}^{-1}$ ) were pour-plated on MPA medium $(20 \mathrm{ml}$ per plate). The plugs with yeast biomass were placed onto MPA containing a lawn of certain bacterial strains. After an incubation period of $24 \mathrm{~h}$ at $37^{\circ} \mathrm{C}$, the diameter of clear zones of the inhibition of the bacterial growth surrounding the plugs with yeasts biomass was measured. As at present there are no fully accepted standard methods for evaluation of microbial antagonism, the values of antagonistic activity in our studies were the widths of the bands of the inhibition zones surrounding the plugs. This will make possible to carry out the comparative analysis of our data with the results coming from the alternative methods $[3,4]$.

All experiments were carried out in triplicates and the results were statistically analysed using Excel and Statistica 12.

Results and Discussion. We studied the antagonistic activity of yeasts isolated from Hucul homemade dairy foods (28 strains) and GIT samples of long-livers (24 strains) of the Carpathian highlands in Ukraine (Table 1). Out of 52 tested yeasts strains totally we found that 7 strains $(13.46 \%)$ manifested antagonistic activity towards bacteria. We evaluated the antagonistic activity as low at band widths 1-9 mm, medium -at 10-19 $\mathrm{mm}$ and high at values $\geq 20 \mathrm{~mm}$. Our experiments showed that, in general, $42.85 \%$ of tested yeasts (3 strains) demonstrated medium antagonistic activity and $57.14 \%$ of yeasts (4 strains) were of low antagonistic activity.

All 7 selected yeast-antagonists were active against Gram-positive bacteria Staphylococcus aureus, and only 3 of them were active toward Gram-negative bacteria Escherichia coli, Citrobacter freundii, Citrobacter intermedius.

The high values of the bacterial growth inhibition, in general, were observed towards the reference strain Staphylococcus aureus ATCC 25922. However the yeasts cultures Rhodotorula sp. S1, Debaryomyces hansenii S3, Debaryomyces hansenii S5, Candida sp. S11, Saccharomyces pasporianus FF7 showed the maximum values of antagonistic activity towards the clinical isolate Staphylococcus aureus 38.

In present study the antagonistic activity of the tested yeasts depended on the source of their isolation clearly demonstrating the predominance of yeastantagonists among the isolates from GIT of long-livers (5 strains) compared to those isolated from dairy food - Hucul yogurt guslinka (2 strains). 
Only three strains out of 7 yeasts manifested antagonistic activity to Gram-negative bacteria. The widths of bacterial growth inhibition zones for Saccharomyces pasterianus FF7 were different for clinical and reference strains of Escherichia coli (Fig. 1C). This yeast strain showed the highest zones of antagonistic activity against the reference $E$. coli strain under acidic conditions with $\mathrm{pH}$ 5.0-5.5. At $\mathrm{pH} 6.0$ and 7.0 the values of inhibition zones did not differ for the reference and clinical E. coli strains (Fig. 1C). Whereas at pH 6.5 Saccharomyces pasterianus FF7 demonstrated significantly higher antagonistic activity towards the clinical E. coli isolate. It was found that Saccharomyces pasterianus FF7 did not show any antagonism towards Citrobacter bacteria (Fig. 1C).

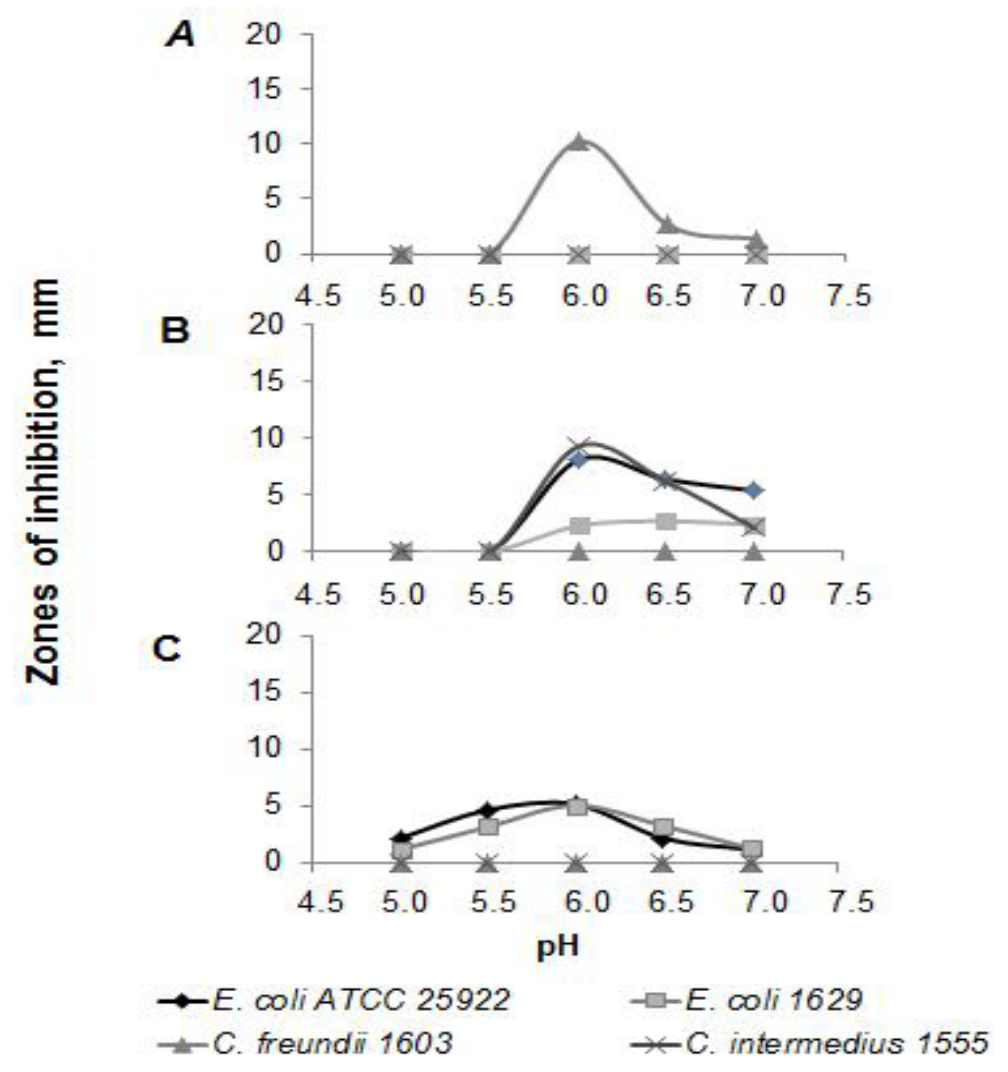

Fig. 1. Antagonistic activity of yeast strains isolated from dairy products and human GIT towards Gram-negative bacteria (genera Escherichia and Citrobacter) at different pH values: A - Debaryomyces hansenii S2; B - Debaryomyces hansenii S3;

C - Sacharomyces pasterianus FF7. Standard errors of mean did not exceed $6 \%$

The difference in the width values of inhibition zones can be caused by the effect of $\mathrm{pH}$ on the antagonistic activity of yeasts metabolites including bacteriocines because the activation of enzymes and the rate of enzymatic reaction are primarily dependent on temperature and $\mathrm{pH}[7,8]$.

Another two antagonistic yeasts against Gram-negative bacteria were GIT strains Debaryomyces hansenii S2 and S3 (Fig. 1 A and B). They antagonistic activity was low (S2 - 10,2 $\mathrm{mm}$ and $\mathrm{S} 3-8,1 \mathrm{~mm} ; 2,3 \mathrm{~mm} ; 9,3 \mathrm{~mm})$. D. hansenii S3 was able to inhibit the growth of 3 bacteria (Escherichia coli ATCC 25922, Escherichia coli 1621, Citrobacter intermedius 1555) whereas D. han- 
senii $\mathrm{S} 2$ possessed antagonistic activity to only one bacterial strain (Citrobacter freundii 1603).

Both guslinka isolates Saccharomyces pasterianus FF7 and FF18 possessed antagonistic activity towards tested Staphylococci (Fig. 2). Despite not being able to inhibit the growth of Gram-negative bacteria $S$. pasterianus FF18 demonstrated the highest observed in this study values of antagonistic activity towards Gram-positive bacteria (Fig. 2B). Thus, its maximum value of the width of the growth inhibition zone of the reference strain Staphylococcus aureus ATCC25923 reached $18.5 \mathrm{~mm}$ at $\mathrm{pH}=5.5$.
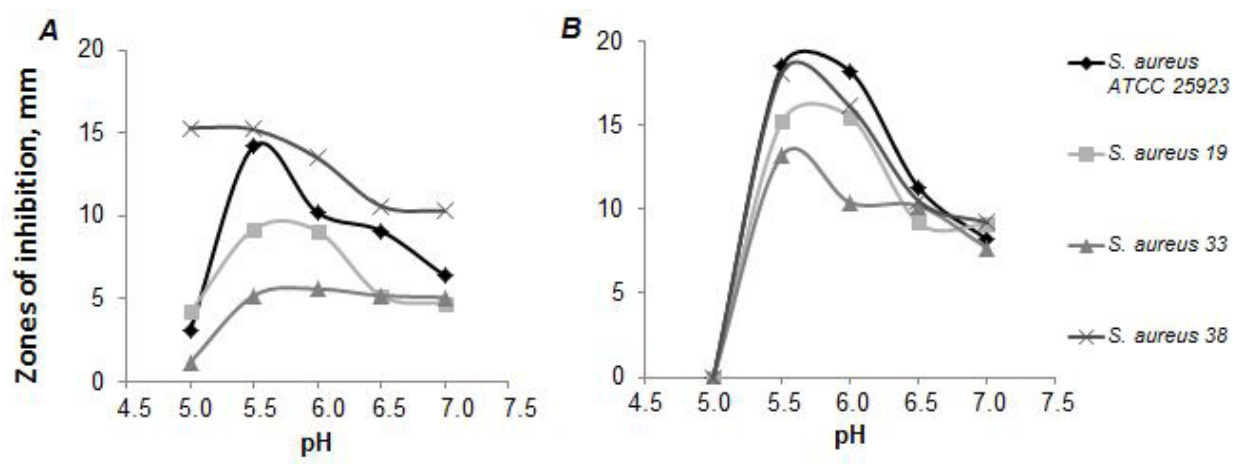

Fig. 2. Antagonistic activity of yeast strains isolated from dairy products towards Grampositive bacteria (Staphylococcus aureus) at different pH values: A - Saccharomyces pasterianus FF7; B - Saccharomyces pasterianus FF18. Standard errors of mean did not exceed $6 \%$

Among the GIT yeasts isolates the antagonistic activity of Debaryomyces hansenii S2, S3 and S5 towards Staphylococci, if any, was low or medium (Fig. 3).

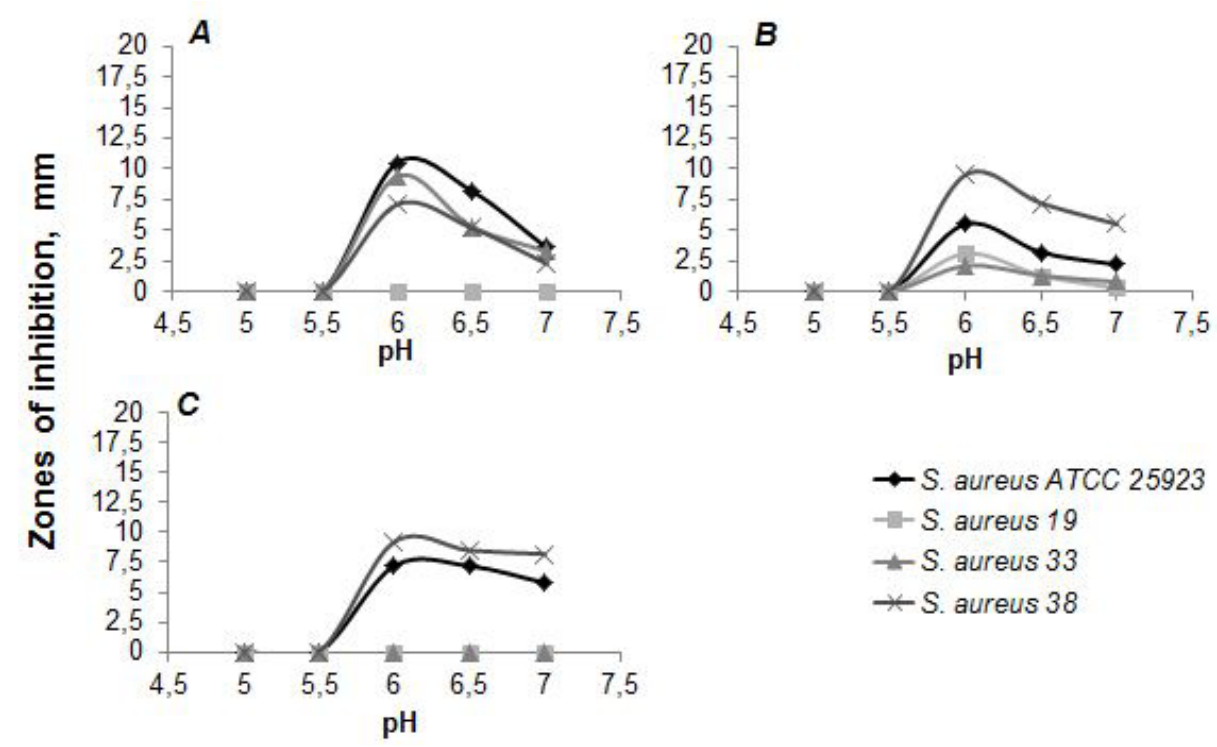

Fig. 3. Antagonistic activity of yeast strains isolated from human GIT towards Grampositive bacteria (Staphylococcus aureus) at different $\mathrm{pH}$ values: A - Debaryomyces hansenii S2; B - Debaryomyces hansenii S3; C - Debaryomyces hansenii S5. Standard errors of mean did not exceed $10 \%$ 
All D. hansenii strains inhibited growth of the reference strain Staphylococcus aureus ATCC25923 however the pattern of their anti-Staphylococci activity differed. D. hansenii strains S2, S3 and S5 manifested antagonistic activity towards 3, 4 and 2 tested $S$. aureus strains, respectively. D. hansenii S2 demonstrated the highest antagonistic activity towards to the reference strain Staphylococcus aureus ATCC25923 (Fig. 3A), whereas D. hansenii S3 and S5 inhibited the reference bacterial strain less than the clinical isolate $S$. aureus 38 (Fig. 3B and 3C).

In general, the anti-Staphylococci activity of Rhodotorula spp. S1 was significantly higher compared to Candida sp. S11. Similarly to D. hansenii S3 and S5, Candida sp. S11 demonstrated considerably higher antagonistic ability towards the clinical isolate Staphylococcus aureus 38 (Fig. 4).

$\boldsymbol{A}$

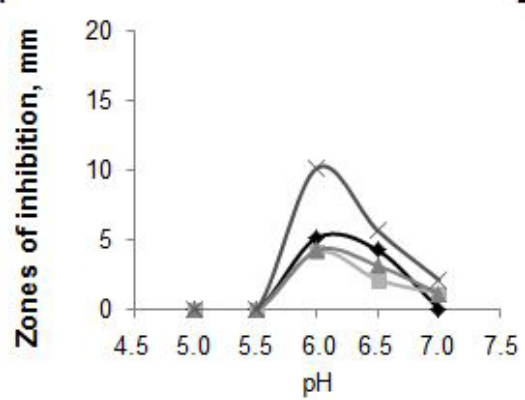

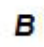

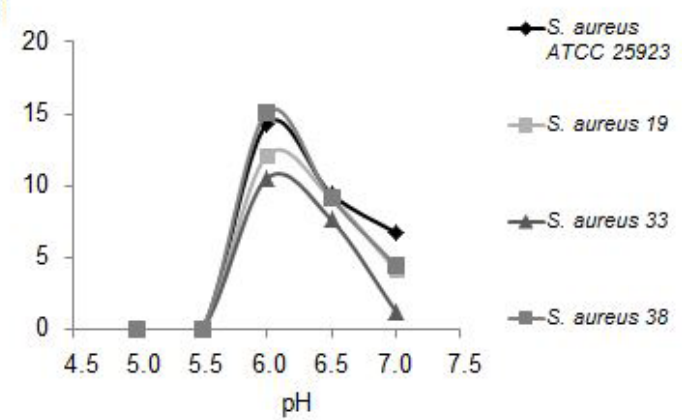

Fig. 4. Antagonistic activity of yeast strains isolated from human GIT towards Grampositive bacteria (Staphylococcus aureus) at different pH values: A - Candida sp. S11;

B - Rhodotorula spp. S1. Standard errors of mean did not exceed $10 \%$

Our results showed the significant differences between the optimal values of $\mathrm{pH}$ for maximum inhibition of the growth of Gram-positive and negative bacteria by yeasts originated from guslinka and GIT. To visualize such differences we plotted the relative data on antagonistic activity of yeasts expressed as a percent of maximum manifested antagonism towards bacteria by each yeast strain (Fig. 5). There were two distinct optimal ranges of $\mathrm{pH}$ values around 5.5 for
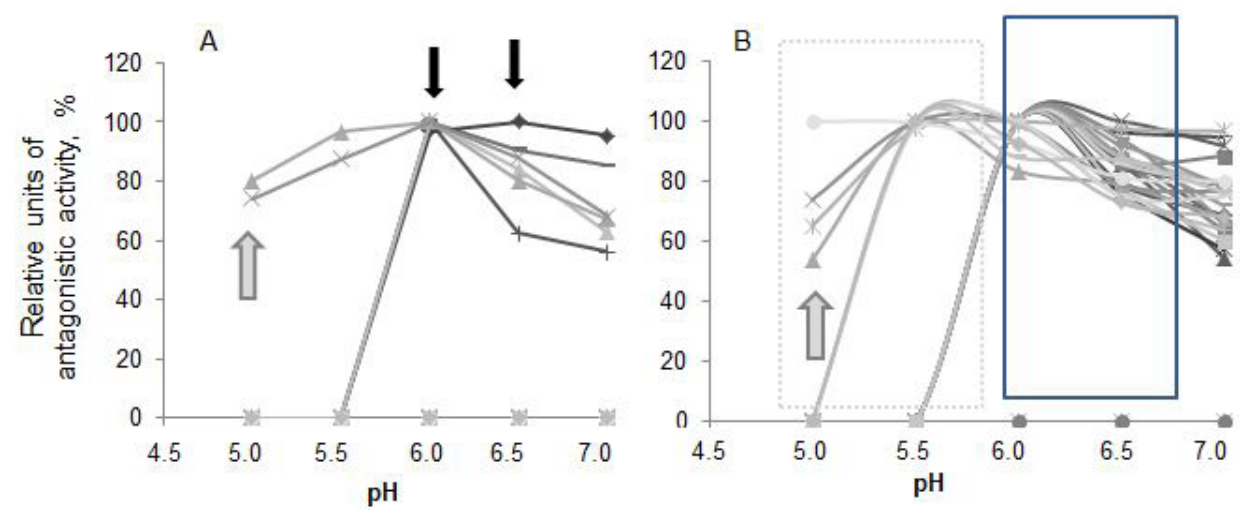

Fig. 5. Relationship between the relative units of yeasts antagonistic activity towards Gram-negative (A) and Gram-positive (B) bacteria and the values of pH. Black arrows (A) and rectangles (B) indicate the presence of two optimal ranges of $\mathrm{pH}$ values for antagonism manifestation, grey arrows $(\mathrm{A}, \mathrm{B})$ indicate the start of the antagonistic action of yeast isolates from guslinka under more acidic conditions. Standard errors of mean did not exceed $10 \%$ 
guslinka strains and 6.5 for GIT strains in the case of antagonism towards Grampositive bacteria. In the case of antagonism towards Gram-negative bacteria the difference between the peaks of optimal $\mathrm{pH}$ values was less pronounced being around 6.0 and 6.5 for guslinka and GIT isolates, respectively (Fig. 5).

We found the different effect of $\mathrm{pH}$ values on antagonistic activity towards bacteria for yeasts of different origin (Fig. 5). Antagonistic activity of the guslinka strains belonging to the species Saccharomyces pasterianus appeared at $\mathrm{pH} 5.0$ whereas the isolated from GIT strains identified as Rhodotorula spp., Candida sp. and Debariomyces hansenii started to manifest the antagonistic activity only at $\mathrm{pH} 6.0$.

This phenomenon of the antagonism manifestation at more acidic $\mathrm{pH}$ values for guslinka yeast isolates can be associated with the difference in the acidity of the environments where these two groups of yeasts originated from: yogurt and GIT. The $\mathrm{pH}$ of the yogurts is usually around 4.5-4.6 due to the lactic acid production by lactic acid bacteria [15]. Whereas the $\mathrm{pH}$ values of healthy human bowel's were reported to vary being in average 6.4 for proximal small bowel, 7.4 for distal small bowel, 6.3 for caecum/right colon and 6.9 for left colon/rectal [14]. It might be suggested that the $\mathrm{pH}$ effect on bactericidal activity manifested by two different groups of yeast-antagonists is related to the different nature of antagonistic reaction, for example the activation of bacteriocines occurring at different values of $\mathrm{pH}$.

It is known that mechanisms of antagonistic activity of yeasts against Grampositive and negative bacteria are different. Antagonistic activity toward Grampositive bacteria was attributed to the action of bacteriocin-like substances inhibiting cellular metabolism of bacteria [5].

The inhibition of growth of Gram-negative bacteria by yeasts is thought to be connected mainly with the action of primary metabolites [5]. Such inhibiting activity is usually low. The substances like phenols, cresols and detergents can manifest antagonistic action towards Gram-negative bacteria affecting both outer membrane and the selective permeability of the plasma membrane [5].

The bacteriostatic and bactericidal effects of yeasts on bacteria can be also contributed by indirect mechanisms, for example, through the production of substances like acids and alcohols changing physico-chemical environment (e.g. $\mathrm{pH}$ ) and in the course of competition for nutrient resources [9].

Thus, as a result of this research out of 52 yeast isolates from homemade dairy products and the Hucul long-livers GIT from the Carpathian highland in Ukraine, we found 7 yeasts with antagonistic activity $(13.46 \%)$, of which 2 strains were food isolates and 5 strains were GIT isolates.

All found yeast-antagonists inhibited Gram-positive bacteria (Staphylococcus aureus) growth and only three isolates showed antibacterial activity towards Gram-negative bacteria (genera Escherichia and Citrobacter).

Optimal $\mathrm{pH}$ ranges for the development of antagonism by different yeasts differed for isolates from different sources. It was demonstrated a general trend that antagonistic activity of yeast isolates from dairy products starts to manifest at more acidic $\mathrm{pH}$ values ( $\mathrm{pH} 5.0$ and 5.5), unlike yeasts isolated from the gastrointestinal tract ( $\mathrm{pH} 6.0$ and 6.5). 


\section{М.О. Фоміна ${ }^{1}$, В.В. Домбровська ${ }^{2}$, К.С. Ткаченко ${ }^{1}$, В.С. Підгорський ${ }^{1}$}

${ }^{1}$ Інститут мікробіології і вірусологї ім. Д.К. Заболотного НАН Украӥни, вул. Академіка Заболотного, 154, Київ, 03143, Украӥна

${ }^{2}$ Навчально-науковий ичентр «Інститут біологіï», Київський національний університет ім. Тараса Шевченка, вул. Володимирська 64/13, Київ, 01601, Україна

\section{ВПЛИВ РН НА АНТАГОНІСТИЧНУ АКТИВНІСТЬ ДРІЖДЖІВ, ІЗОЛЬОВА- НИХ 3 КИСЛОМОЛОЧНИХ ПРОДУКТІВ ТА ШЛУНКОВО-КИШКОВОГО ТРАКТУ ЛЮДИНИ}

\section{Резюме}

Метою цієї роботи було вивчити вплив рН поживного середовища на антагоністичну активність ізолятів дріжджів із автентичних гуцульських кисломолочних продуктів та шлунково-кишкового тракту гуцулів-довгожителів до умовно-патогенних бактерій для людини і тварин. Серед 52 досліджених дріжджових ізолятів $14 \%$ показали значну антагоністичну активність проти грампозитивних бактерій Staphylococcus aureus; 3 них тільки 6 \% інгібували ріст грамнегативних бактерій, що належать до родів Escherichia та Citrobacter. Більшість дріжджів з антагоністичною активністю (більше 70 \%) було виділено з шлунково-кишкового тракту довгожителів. Також було визначено два оптимальні діапазони значень рН поживного середовища для виявлення антагоністичної активності досліджуваних дріжджів, що складало біля 5,5 і 6,0 для грампозитивних бактерій, та біля 6,0 і 6,5 - для грамнегативних бактерій. Показано, що дріжджі Saccharomyces pasterianus, ізольовані з гуцульського йогурту, проявляють антагоністичну активність за більш кислих умов, ніж ізоляти 3 шлунково-кишкового тракту людини.

Ключ о в $i$ сл о в $а$ : дріжджі, антагоністична активність, $\mathrm{pH}$, кисломолочні продукти, шлунково-кишковий тракт.

\section{М.А. Фомина ${ }^{1}$ И.В. Домбровская ${ }^{2}$, К.С. Ткаченко ${ }^{1}$ В.С. Подгорский}

${ }^{1}$ Институт микробиологии и вирусологии им. Д.К. Заболотного НАН Украинь,, ул. Академика Заболотного, 154, Киев, 03143, Украина

${ }^{2}$ Учебно-образовательный цеентр «Институт биологии», Киевский национальный университет им. Тараса Шевченко, ул. Владимирская, 64/13, Киев, 01601, Украина

\section{ВЛИЯНИЕ РН НА АНТАГОНИСТИЧЕСКУЮ АКТИВНОСТЬ ДРОЖЖЕЙ, ИЗОЛИРОВАННЫХ ИЗ КИСЛОМОЛОЧНИХ ПРОДУКТОВ И ЖЕЛУДОЧНО-КИШЕЧНОГО ТРАКТА ЧЕЛОВЕКА}

\section{Резюме}

Целью этой работы было изучить влияние рН питательной среды на антагонистическую активность изолятов дрожжей из аутентичных гуцульских кисломолочных продуктов и желудочно-кишечного тракта гуцулов-долгожителей к условно-патогенным бактериям человека и животных. Среди 52 исследованных дрожжевых изолятов 14 \% показали значительную антагонистическую активность против грампозитивных бактерий Staphylococcus aureus; из них только 6 \% ингибировали рост грамнегативных бактерий, принадлежащих к родам Escherichia и Citrobacter. Большинство дрожжей с антагонистической активностью (более 70 \%) было выделено из желудочно-кишечного тракта долгожителей. Также нами были 
найдены оптимальные диапазоны значений рН питательной среды для выявления антагонистической активности исследованных дрожжей, что составило около 5,5 и 6,0 для грампозитивных бактерий, и около 6,0 и 6,5 - для грамнегативных бактерий. Показано, что дрожжи Saccharomyces pasterianus, изолированные из гуцульского йогурта, проявляют антагонистическую активность при более кислых условиях, нежели изоляты из ЖКТ человека.

Ключ е в bl е сло в а: дрожжи, антагонистическая активность, $\mathrm{pH}$, кисломолочные продукты, желудочно-кишечный тракт.

1. Бабьева И.П., Чернов И.Ю. Биология дрожжей. - Москва: Товарищество научных изданий КМК, 2004. - 239 с.

2. Квасников Е.И., Щелокова И.Ф. Дрожжи. Биология. Пути использования. К.: Наук. думка, 1991. -328 с.

3. Нагорная С.С., Жарова В.П., Котляр А.Н. Дрожжи-антагонисты в нормальной микрофлоре кишечного тракта долгожителей Абхазии // Микробиологический журнал. - 1989. - 51, № 5. - С. 34-39.

4. Промышленная микробиология: Учеб. пособие для вузов / З.А. Аркадьева, А.М. Безбородов, И.Н. Блохина и др.; Под ред. Н.С. Егорова. - Москва: Высш. шк., 1989. -688 с.

5. Фролова Я.Н. Антагонистическая активность метаболитов Saccharomyces cerevisiae к симбиотическим микроорганизмам ЖКТ человека // Альманах современной науки и образования, Тамбов: - 2009. - 4, № 11. - С. 197-199.

6. Bab'eva I.P., Chernov I.Yu. Geographical aspects of yeast ecology // Phisiol.Gen.Biol. Rev. - 1995. - N 9. - P. 3.

7. Graff Sandrine, Chaumeil Jean-Claude, Pierre Boy and al. Influence of $\mathrm{pH}$ conditions on the viability of Saccharomyces boulardii yeast // J.Gen.Appl.Microbiol. - 2008. N 54. - P. 221-227.

8. Hatoum R., Labrie S., Fliss I. Antimicrobial and probiotic properties of yeasts: from fundamental to novel applications // Frontiers in Microbiology. - 2012. - N 3. - . P. 421-433.

9. Kumura H., Tanoue Y., Tsukahara M., Takana T., Shimazaki K. Screening of Dairy yeast strains for probiotic Applications // J. Dairy Sci. - 2004. - N 87. - P. 4050-4056.

10. Kurtzman C.P., Fell J.W., Boekhout T. The Yeasts: A Taxonomic Study. 5th edn. - Elsevier Science B.V., 2011 - 1053 p.

11. Marquina D., Santos J.A., Peinado J.M. Biology of killer yeasts // Int. Microbiology. 2002. - N 5. - P. 65-71.

12. Mattanovich D., Sauer M., Gasser B. Yeast biotechnology: teaching the old dog new tricks // Microb Cell Fact. - 2014. - N 13. - P. 34-39.

13. Muccilli S., Restuccia C. Bioprotective role of yeasts // Microorganisms. - 2015. N 3. - P. 588-611.

14. Nugent S.G., Kumar D., Rampton D.S., Evans D.F. Intestinal luminal pH in inflammatory bowel disease: possible determinants and implications for therapy with aminosalicylates and other drugs. Gut. - 2001. - 48, N 4. - P. 571-577.

15. Ozcan Tulay. Determination of Yogurt Quality by Using Rheological and Textural Parameters 2nd International Conference on Nutrition and Food Sciences. - 2013. N 53. - P. 23. 